\title{
Profile of Hanwoo Steer Carcass Characteristics, Meat Quality and Fatty Acid Composition after Feeding Italian Ryegrass Silage
}

\author{
Won Ho Kim, Suk-Nam Kang ${ }^{1 *}$, Mariadhas Valan Arasu, Gyo-Moon $\mathrm{Chu}^{2}$, Da Hye Kim², \\ Jae-Hong Park ${ }^{4}$, Young Kyoon $\mathrm{Oh}^{5}$, and Ki Choon Choi* \\ Grassland and Forage Division, National Institute of Animal Science, RDA, Cheonan 330-801, Korea \\ ${ }^{1}$ Department of Animal Resources, Daegu University, Gyeongsan 712-714, Korea \\ ${ }^{2}$ Feed Research Institute Nonghyup Feed Inc., Seoul 134-763, Korea \\ ${ }^{3}$ The United Graduate School of Agricultural Sciences, Tottori University, Tottori-Shi 680-8553, Japan \\ ${ }^{4}$ Department of Animal Resource and Science, Dankook University, Cheonan 303-714, Korea \\ ${ }^{5}$ Animal Nutrition and Physiology Team, National Institute of Animal Science, RDA, Suwon 441-706, Korea
}

\begin{abstract}
The objective of this work was to evaluate the growth performance, feed intake, slaughter characteristics, meat quantity and quality characteristics of Hanwoo steers fed with Italian ryegrass (IRG) silage (TRT). IRG silage consisted $11.70 \%$ protein, $2.84 \%$ ether extract, $53.50 \%$ dry matter digestibility and $63.34 \%$ total digestible nutrients. The daily weight gain and feed conversion ratio of TRT were significantly $(p<0.01)$ higher than that of control diet (CON; fed rice straw) in the whole periods. However, the slaughter weight, dressing percentage, quantity grade and quantity traits (marbling score, meat color, fat color, and quality grade) of either TRT or CON were similar. Meat fed TRT diet showed higher crude fat and lightness $\left(\mathrm{L}^{*}\right)$ value and lower moisture content and $\mathrm{pH}$ value compared with the CON diet $(p<0.05)$. Overall the carcass yield was $12.5 \%$ higher than CON diet.
\end{abstract}

Keywords: Italian ryegrass silage, Hanwoo steers, carcass characteristics, meat quality, fatty acid profiles

Received September 27, 2014; Revised January 21, 2015; Accepted January 25, 2015

\section{Introduction}

It is widely recognized that diet plays a major role in modulating the fatty acid composition of cattle (Jensen, 2002), goats (Chilliard et al., 2003) and sheep (Bocquier and Caja, 2001). However, feed costs represent the largest single variable cost in beef production in Korea. Contributing to this situation is high operating costs, where the feed component is the major cost of total cost. The grass is the cheapest source of feed available for beef (and milk) production, which provided that the environment and management permit high yields of high-quality herbage to be utilized (McGee, 2005). Production and efficient utilization of high yields of high nutritive value grass throughout an extended grazing season are critical

\footnotetext{
*Corresponding authors: Ki Choon Choi, Grassland and Forage Division, National Institute of Animal Science, RDA, Cheonan 330-801, Korea. Tel: +82-41-580-6752, Fax: +82-41-580-6779; E-mail: choiwh@korea.kr; Suk-Nam Kang; Department of Animal Resources, Daegu University, Gyeongsan 712-714, Korea. Tel: +82-53-850-6725, Fax: +82-53-850-6729; E-mail: sk-kang (a)daegu.ac.kr
}

for cost efficient beef production (O'Riordan et al., 2000). Production of beef cattle fed with grass silage diet supplements containing a high source of protein have been evaluated (Keating et al., 1990; Petit et al., 1994; Steen, 1984; Veira et al., 1988). Grass-feed based production systems are low-input methods that are particularly suitable to meet the demand of meat retailers and consumers for the naturalist and animal-friendly production of beef (Razminowicz et al., 2006). Therefore, in Korea, the combination of roughage and concentration commonly available in the market is used to rear Hanwoo. Especially, the study of manufacturing silage using whole crop barley silage or whole crop rye silage was carried out to expand the usage of roughage (Shinekhuu et al., 2010). Italian ryegrass (Lolium multiflorum Lam.; IRG) is an important crop cultivated for the production of highquality forage in temperate regions around the world for various purposes. It is a preferred forage crop due to its fast growth, palatability, high forage yield and good nutritional quality. It is utilised as green forage or silage. Fresh as well as dry matter (DM) yield and nutritional quality of IRG vary considerably with varieties, the stages at 
which harvested, climatic conditions and agronomic factors. However, the benefits of feeding diet combinations of concentrate and IRG silages from growing period to finishing period of Hanwoo steer have not been evaluated. In order to determine the efficacy of the IRG silage/ concentrate feeding system for Hanwoo steer, it was essential to conduct feeding trials to evaluate the IRG silage combined with concentrate system and compare to a traditional rice straw combined with concentrate based system. The objectives of this study were to compare the growth performance, and carcass quality of Hanwoo steer fed IRG silage/concentrate and rice straw/concentrate diet, and meat quantity and quality characteristics.

\section{Materials and Methods}

\section{Experimental design and animal management}

This experiment was conducted according to the Hanwoo care and user guidelines of the National Livestock
Research Institute of Korea. The calves of Hanwoo steers were obtained upon weaning (body weight of $190.00 \pm$ $26.64 \mathrm{~kg}$ and from 120 to $180 \mathrm{~d}$ of age) and maintained in the individual feeding barn of the National Institute of Animal Science in Korea and cared according to the Hanwoo guidelines of the National Livestock Research Institute of Korea (MFAFF, 2007). Hanwoo steers (4-6 mon age) were individually penned and fed the experimental diets twice daily at 09:00 AM and 16:00 PM and had free access to mineral blocks. Each treatment was fed to steers via an individual gate feeding system.

Twenty-four Hanwoo steer were used in this experiment that lasted for $739 \mathrm{~d}$ (August 2008-September, 2010). Hanwoo steers were randomly allotted to two treatments (three pens per treatment, four Hanwoo steers per pen) and then investigated by stage of each period. Average body weight $\pm \mathrm{SD}$ at the start of the experiment was $212.40 \mathrm{~kg}$ for the control and $167.60 \mathrm{~kg}$ for the treatment, respectively. Animals were fed in a semi-covered barn

Table 1. Ingredient composition and chemical analysis of the experimental diets

\begin{tabular}{|c|c|c|c|c|}
\hline & Growing period & Early fattening period & Middle fattening period & Late fatting period \\
\hline Cornflake & 25.00 & 29.00 & 30.00 & 35.00 \\
\hline Barley & - & - & - & 8.00 \\
\hline Cottonseed whole & - & - & - & 3.00 \\
\hline Wheat & 18.00 & 18.00 & 18.00 & 18.00 \\
\hline Gluten feed & 8.00 & 9.58 & 12.00 & 3.00 \\
\hline Rice bran polished & - & 1.00 & 2.36 & 1.93 \\
\hline Tapioca residue & 4.58 & 6.22 & 5.23 & 5.23 \\
\hline Wheat bran & 11.79 & 12.40 & 13.81 & 6.34 \\
\hline Palm kernal meal & 8.00 & 5.00 & 3.00 & 2.05 \\
\hline Coconut oil meal & 3.00 & 2.00 & 1.00 & 1.00 \\
\hline Rapseed meal & 5.00 & 3.00 & 3.00 & 2.00 \\
\hline Soybean meal & 7.39 & 3.28 & 0.94 & 2.12 \\
\hline Distillers dried grains & 2.22 & 3.50 & 4.00 & 5.71 \\
\hline Limestone & 2.17 & 2.31 & 1.75 & 1.64 \\
\hline Molasses & 3.00 & 3.00 & 3.00 & 3.00 \\
\hline Salt & 0.81 & 0.81 & 0.69 & 0.69 \\
\hline Probiotics & 0.05 & 0.10 & 0.10 & 0.10 \\
\hline Magnesium oxide & 0.30 & 0.30 & 0.30 & 0.30 \\
\hline Sodium bicarbonate & 0.30 & 0.30 & 0.50 & 0.50 \\
\hline Mineral premix ${ }^{a}$ & 0.21 & 0.21 & 0.21 & 0.21 \\
\hline Vitamin premix ${ }^{b}$ & 0.18 & - & 0.10 & 0.18 \\
\hline Total & 100.00 & 100.00 & 100.00 & 100.00 \\
\hline Dry matter (\%) & 87.71 & 87.32 & 87.21 & 87.06 \\
\hline Crude protein $(\%$ of DM) & 16.00 & 14.00 & 13.72 & 12.39 \\
\hline Acid detergent fiber ( $\%$ of DM) & 9.37 & 10.05 & 8.14 & 8.16 \\
\hline Neutral detergent fiber (\% of DM) & 26.28 & 26.06 & 24.43 & 22.67 \\
\hline TDN & 70.17 & 72.07 & 73.30 & 75.00 \\
\hline
\end{tabular}

${ }^{a}$ Steers had free access to mineral blocks (Rincal block, Daehan New Pham, Korea; provided following nutrients per kg: I, $150 \mathrm{mg}$; Mn, 200 mg; S, 4,000 mg; Co, 100 mg; Fe, 2,000 mg; Zn, 100 mg; Ni, 50 mg; Cu, 100 mg; Mg, 3,000 mg; Ca, 2,000 mg; Se, 40 g; NaCl, $380 \mathrm{~g})$ throughout the experiment.

${ }^{\mathrm{b}}$ Provided following nutrients per kg of additive (Grobic-DC, Bayer HealthCare, Germany): Vitamin A, 2,650,000 IU; Vitamin D3, 530,000 IU; Vitamin E, 1,050 IU; Niacin, 10,000 mg; Mn, 4,400 mg; Zn, 4,400 mg; Fe, 13,200 mg; Cu, 2,200 mg; I, 440 mg; Co, 440 mg. 
with two pens per treatment. Animals had ad libitum access to fresh water. At the end of the feeding trial, all animals were slaughtered at a commercial abattoir (National Agricultural Cooperative Federation, Korea).

The rice straw was purchased from a beef cattle farm and chopped to $4-5 \mathrm{~cm}$ lengths. The IRG was grown on a research farm at National Livestock Research Institute of Korea, harvested at heading stage and packed with Lactobacillus plantarum in round bale wrapper using the silage wrapping machine, and IRG silage was stored for $90 \mathrm{~d}$. Ingredient composition and chemical analysis of the concentrate diets were showed in Table 1.

Lactobacillus plantarum strain procured from ChungMi Bio Co., Korea was used for the preparation of silage. All animals were also fed concentrate diets for each growing period. After feeding the roughage or silage, the concentrate was offered each feeding time. The leftover feed is collected every day just before the evening feeding time (17:00) to measure the feed intake. The classification of growing period was divided into initial period for $137 \mathrm{~d}$, first fattening period for $124 \mathrm{~d}$, mid fattening period for 184 days, finish fattening period for $295 \mathrm{~d}$, and a final period of $739 \mathrm{~d}$, respectively, from the beginning of feeding period. Random grab samples of rice straw and IRG silage were taken monthly and were ground through a $1 \mathrm{~mm}$ screen for the proximal analysis by the method of AOAC (1995). The chemical composition of rice straw or IRG silage was analyzed.

\section{Chemical composition analyses}

The dry matter content of the rice straw and IRG silages were determined by freeze-drying for at least $24 \mathrm{~h}$. Crude ash was obtained at $550^{\circ} \mathrm{C}$ for $5 \mathrm{~h}$. The crude protein, ether extract, and crude ash were determined by AOAC (1995). Digestible energy values were calculated from the total digestible nutrients (TDN) using the factors suggested by the NRC (2001), and the data were subjected to analysis of variance (Snedecor and Cochran, 1968).

\section{Measurements and analyses}

All the steers were slaughtered for the examination of carcass characteristics. Samples of intramuscular (M. longissimusdorsi) (LM) at the 13-14th ribs were taken and ground, and mixed well for fatty acids analysis. Carcasses were weighed immediately post the slaughter process, and then chilled at $4^{\circ} \mathrm{C}$ for $48 \mathrm{~h}$. The day after slaughtering, the left side of the carcass was ribbed between the last rib and the first lumbar vertebrae to evaluate carcass traits. After 30 min of blooming period, evaluation was performed for quantity grade $(5=$ grade $\mathrm{A}$ to $2=$ grade $\mathrm{D})$, marbling score $(1=$ low fat to $5=$ high fat $)$, meat color $(1$ $=$ very light cherry red to $7=$ very dark red $)$, fat color $(1$ $=$ white to $7=$ yellow $)$, texture $(1=$ very fine to $3=$ very coarse), maturity ( 1 = below 15 mon old to $15-26$ mon old $=2)$, and quality grade $\left(7=\right.$ grade $1^{+}$to grade $\left.3=1\right)$ on the basis of Animal Products Grading Service (APGS) manual (2007). Briefly, back fat thickness was determined by measuring, perpendicular to the outside surface, at a point two-thirds of the length of the rib-eye ribbed between the last rib and the first lumbar vertebrae. The area of the rib-eye was determined at the surface of the cut using a standard grid. Ten grams of chopped meat was mixed with $10 \mathrm{~mL}$ deionized water. The $\mathrm{pH}$ of the slurry was measured using the $\mathrm{pH}$ meter (F-12, Horiba, Japan). The cooking loss was performed as described by Kang et al. (2010). The sample of cooking loss was then used for the shear force assessment. The sample was cut into 1 $\mathrm{cm}^{2}$ cross section with the fiber direction and $1.5 \mathrm{~cm}$ in length. The shear force was measured using a texture analyzer (TA-XT2i, Stable Microsystems Ltd., UK) equipped with a $25 \mathrm{~kg}$ load cell, a Warner-Bratzler shear blade, and a test speed setting at $2.0 \mathrm{~mm} / \mathrm{s}$. Only the maximum force $(\mathrm{kg})$ was taken into account. Part of meat samples were cut into pieces of $2 \mathrm{~cm}$ in width, $4 \mathrm{~cm}$ in length and 0.5 $\mathrm{cm}$ in thickness. In addition, they were roasted using the electronic pan for home use until the internal temperature of $73^{\circ} \mathrm{C}$ was attained.

\section{Fatty acid analysis}

The total contents of lipids were extracted from the ground LM. Tissues were homogenized in chloroform/ methanol solution (Folch et al., 1957) using a homogeizer (PT-MR3100, Switzerland). The chloroform recovered from the measured aliquots of the extract was evaporated in the dry bath (Type $16500, \mathrm{USA}$ ) at $50^{\circ} \mathrm{C}$ using nitrogen gas. Methylation of the lipids extracted followed the method of Lepage and Roy (1986) prior to injecting into a gas chromatograph (HP 5890 II fixed with a G1513A autosampler, Hewlett-Packard Co.). A fused silica capillary column $(100 \mathrm{~m} \times 0.25 \mathrm{~mm}$, i.d. $\times 0.20 \mu \mathrm{m}$ thickness, Supelco, SP TM-2560, USA) was used for the fatty acid analyses and ultra-pure helium was used as the carrier gas (flower rate $=1.0 \mathrm{~mL} / \mathrm{min}$ ). The injector and detector temperature was maintained at $250^{\circ} \mathrm{C}$. The initial oven temperature was $140^{\circ} \mathrm{C}$ (held for $30 \mathrm{~min}$ ), and then increased by $15^{\circ} \mathrm{C} / \mathrm{min}$ to $220^{\circ} \mathrm{C}$ (held for $40 \mathrm{~min}$ ). 


\section{Statistical analysis}

Samples were analyzed in triplicate, and the data were presented as mean \pm standard error of the means. The pen was considered as the experimental unit. An analysis of variance was performed on all the variables measured using the general linear model procedure of the SAS statistical package (Statistics Analytical System, USA, 2002). The Duncan's multiple range tests were used to determine differences between treatment means.

\section{Results and Discussion}

\section{Performance and characteristics}

The nutrient composition of rice straw and IRG silage are shown in Table 2. Results revealed that the percent of crude protein in IRG silage was significantly higher $(11.70 \%)$. The other components of IRG silage such as ether extract $(2.84 \%)$, in vitro dry matter digestibility (IVDMD) (53.50\%), total digestible nutrient (TDN) (63.34\%), lower dry matter (68.04\%), crude ash $(12.70 \%)$ and neutral detergent fiber (55.32\%) were comparatively higher than those of rice straw $(p<0.05)$. The chemical compositions of the silages used are typical of well-pre- served, lactate silages (McDonald and Edwards, 1976). The nutrition value of IRG silage in this study was similar to the silage of barley and ryegrass (Kim et al., 2003; McIsacc and Lovering, 1982). Kunelius and Narasimhalu (1983) and Narasimhalu et al. (1985) also reported that ryegrass harvested annually showed high crude protein (160-190 $\left.\mathrm{g} \mathrm{kg}^{-1} \mathrm{DM}\right)$ that results in high quality of forage for ruminants. In this study, Hanwoo steers were fed a diet consisting of $2.41 \mathrm{~kg}$ DM rice straw and $7.41 \mathrm{~kg}$ DM concentrate for the control group and $4.00 \mathrm{~kg}$ DM IRG silage and 6.20 concentrate on treatment group per a day, respectively (See Materials and methods). Tables 3 and 4 show the effects of feeding IRG silage/concentrate diet on growth performance and feed intake of Hanwoo steers while growing, first, middle and finish fattening period. The effects of feeding IRG silage/concentrate on growth performance and feed intake of Hanwoo steers during the whole period are shown in Table 5. In the middle fattening period, the final body weight of the group fed IGR silage/concentrate diet (Treatment) $(554.90 \mathrm{~kg})$ were significantly higher than those of the control group $(\mathrm{CON})$, although the initial body weight of CON and IRG groups were 212.40 and $167.60 \mathrm{~kg}$ respectively. However, the

Table 2. Nutrient composition of rice straw and Italian ryegrass (IRG) silage (\%)

\begin{tabular}{|c|c|c|c|c|}
\hline & Rice straw & IRG silage & $\mathrm{SEM}^{1}$ & $\overline{\mathrm{Pr}}>\mathrm{F}^{2}$ \\
\hline Dry matter (DM) & 90.01 & 68.04 & 4.56 & 0.01 \\
\hline Crude protein $(\mathrm{CP})$ & 3.62 & 11.70 & 1.01 & 0.01 \\
\hline Ether extract (EE) & 1.90 & 2.84 & 0.32 & 0.01 \\
\hline Crude ash (CA) & 32.41 & 12.70 & 1.22 & 0.01 \\
\hline Neutral detergent fiber (NDF) & 80.02 & 55.32 & 2.58 & 0.01 \\
\hline Acid detergent fiber (ADF) & 53.14 & 32.70 & 3.60 & 0.01 \\
\hline In vitro dry matter digestibility (IVDMD) & 51.63 & 53.50 & 0.82 & 0.05 \\
\hline Total digestible nutrient (TDN) & 47.03 & 63.34 & 2.46 & 0.01 \\
\hline
\end{tabular}

${ }^{1}$ Standard error of the mean. ${ }^{2}$ Probability levels.

Table 3. Effects of feeding IRG silage/concentrate on growth performance and feed intake of Hanwoo steers during growing and first fattening period

\begin{tabular}{|c|c|c|c|c|c|c|c|c|}
\hline \multirow{2}{*}{ Items } & \multicolumn{4}{|c|}{ Growing period } & \multicolumn{4}{|c|}{ Early fattening period } \\
\hline & $\mathrm{CON}^{1}$ & $\mathrm{~T}^{2}$ & $\mathrm{SEM}^{3}$ & $\operatorname{Pr}>F^{4}$ & $\mathrm{CON}$ & $\mathrm{T}$ & SEM & $\operatorname{Pr}>F$ \\
\hline Initial body weight (kg) & 212.40 & 167.60 & 4.38 & 0.00 & 305.90 & 314.90 & 13.37 & 0.64 \\
\hline Final body weight (kg) & 305.90 & 314.90 & 13.37 & 0.64 & 376.30 & 407.70 & 14.85 & 0.15 \\
\hline Daily weight gain $(\mathrm{kg})^{5}$ & 0.68 & 1.08 & 0.12 & 0.03 & 0.57 & 0.75 & 0.07 & 0.09 \\
\hline Feed intake $(\mathrm{kg})^{6}$ & 6.61 & 8.50 & 0.30 & 0.01 & 11.59 & 12.47 & 0.32 & 0.13 \\
\hline Concentrate $(\mathrm{kg})^{7}$ & 3.68 & 3.22 & 0.16 & 0.11 & 7.09 & 4.93 & 0.15 & 0.00 \\
\hline Rice straw $(\mathrm{kg})^{8}$ & 2.93 & 0.00 & - & - & 4.50 & 0.00 & - & - \\
\hline IRG silage $(\mathrm{kg})^{9}$ & 0.00 & 5.28 & - & - & 0.00 & 7.54 & - & - \\
\hline Feed efficiency & 0.10 & 0.13 & 0.02 & 0.31 & 0.05 & 0.06 & 0.01 & 0.19 \\
\hline Feed conversion ration & 13.47 & 8.98 & 2.18 & 0.16 & 21.04 & 18.58 & 1.45 & 0.25 \\
\hline
\end{tabular}

${ }^{1} \mathrm{CON}$ : Rice straw + concentrate, ${ }^{2} \mathrm{~T}$ : Italian ryegrass silage+concentrate. ${ }^{3}$ Standard error of the mean. ${ }^{4}$ Probability levels. ${ }^{5}$ Total weight gain and daily weight gain calculated for each animal per a day that it received the test diets. ${ }^{6-9} \mathrm{Feed}$ intake, concentrate, and rice straw/IRG silage calculated for each animal for each period that it received the test diets ( $\mathrm{kg} / \mathrm{head} / \mathrm{day}, \mathrm{DM}$ basis). 
Table 4. Effects of feeding IRG silage/concentrate on growth performance and feed intake of Hanwoo steers during middle fattening and finish fattening period

\begin{tabular}{|c|c|c|c|c|c|c|c|c|}
\hline \multirow{2}{*}{ Items } & \multicolumn{4}{|c|}{ Middle fattening period } & \multicolumn{4}{|c|}{ Late fatting period } \\
\hline & $\mathrm{CON}^{1}$ & $\mathrm{~T}^{2}$ & $\mathrm{SEM}^{3}$ & $\operatorname{Pr}>F^{4}$ & $\mathrm{CON}$ & $\mathrm{T}$ & SEM & $\operatorname{Pr}>F$ \\
\hline Initial body weight (kg) & 376.30 & 407.70 & 14.85 & 0.15 & 501.00 & 554.90 & 17.25 & 0.04 \\
\hline Final body weight (kg) & 501.00 & 554.90 & 17.25 & 0.04 & 676.10 & 735.40 & 23.46 & 0.09 \\
\hline Daily weight gain $(\mathrm{kg})^{5}$ & 0.68 & 0.80 & 0.05 & 0.08 & 0.59 & 0.61 & 0.03 & 0.72 \\
\hline Feed intake $(\mathrm{kg})^{6}$ & 11.40 & 11.43 & 0.49 & 0.96 & 9.57 & 9.24 & 0.21 & 0.33 \\
\hline Concentrate $(\mathrm{kg})^{7}$ & 8.66 & 6.96 & 0.21 & 0.00 & 8.49 & 7.63 & 0.23 & 0.06 \\
\hline Rice straw $(\mathrm{kg})^{8}$ & 2.73 & 0.00 & - & - & 0.00 & 1.60 & - & - \\
\hline IRG silage $(\mathrm{kg})^{9}$ & 0.00 & 4.48 & - & - & 1.08 & 0.00 & - & - \\
\hline Feed efficiency & 0.06 & 0.07 & 0.00 & 0.16 & 0.06 & 0.07 & 0.00 & 0.36 \\
\hline Feed conversion ration & 17.36 & 14.80 & 0.97 & 0.08 & 16.28 & 15.89 & 0.99 & 0.78 \\
\hline
\end{tabular}

${ }^{1} \mathrm{CON}$ : Rice straw+concentrate, ${ }^{2} \mathrm{~T}$ : Italian ryegrass silage+concentrate. ${ }^{3}$ Standard error of the mean. ${ }^{4}$ Probability levels. ${ }^{5}$ Total weight gain and daily weight gain calculated for each animal per a day that it received the test diets. ${ }^{6-9}$ Feed intake, concentrate and rice straw/IRG silage calculated for each animal for each period that it received the test diets ( $\mathrm{kg} / \mathrm{head} / \mathrm{day}, \mathrm{DM}$ basis).

Table 5. Effects of feeding IRG silage/concentrate on growth performance and feed intake of Hanwoo steers during whole period

\begin{tabular}{|c|c|c|c|c|}
\hline \multirow{2}{*}{ Items } & \multicolumn{4}{|c|}{ Whole period } \\
\hline & $\mathrm{CON}^{1}$ & $\mathrm{~T}^{2}$ & $\mathrm{SEM}^{3}$ & $\operatorname{Pr}>F^{4}$ \\
\hline Daily weight gain $(\mathrm{kg})^{5}$ & 0.63 & 0.77 & 0.034 & 0.01 \\
\hline Feed intake $(\mathrm{kg})^{6}$ & 9.83 & 10.20 & 0.11 & 0.08 \\
\hline Concentrate $(\mathrm{kg})^{7}$ & 7.42 & 6.20 & 0.09 & 0.00 \\
\hline Rice straw $(\mathrm{kg})^{8}$ & 2.41 & 0.00 & - & - \\
\hline IRG silage $(\mathrm{kg})^{9}$ & 0.00 & 4.00 & - & - \\
\hline Feed efficiency & 0.06 & 0.08 & 0.00 & 0.07 \\
\hline Feed conversion ration & 16.22 & 13.44 & 0.78 & 0.02 \\
\hline
\end{tabular}

${ }^{1} \mathrm{CON}$ : Rice straw + concentrate, ${ }^{2} \mathrm{~T}$ : Italian ryegrass silage+concentrate. ${ }^{3}$ Standard error of the mean. ${ }^{4}$ Probability levels. ${ }^{5}$ Total weight gain and daily weight gain calculated for each animal per a day that it received the test diets. ${ }^{6-9} \mathrm{Feed}$ intake, concentrate and rice straw/IRG silage calculated for each animal for each period that it received the test diets ( $\mathrm{kg} / \mathrm{head} / \mathrm{day}, \mathrm{DM}$ basis).

final body weight of Hanwoo steers fed either IRG silage/ concentrate or rice straw/concentrate diet in the growing, first and finish fattening periods were similar. The daily weight gain of steer fed treatment diet was significantly higher than that of $\mathrm{CON}$ diet during the period of growing and middle fattening $(p<0.05)$, whereas no significant difference was found in the period of middle and finish fattening period $(p>0.05)$. As a whole, the daily weight gain of treatment was significantly $(p<0.01)$ higher than that of CON (Table 5). The daily weight gain of treatment was higher $57.54 \%, 31.82 \%, 18.04 \%$, and $5.10 \%$ compared with $\mathrm{CON}$ in the growing, first fattening, middle fattening and finish the fattening period, respectively. This result indicated that the increase in daily weight gain of the growing period was relatively higher than those of other periods $(p<0.05)$. In addition, we could suggest that the whole period of the daily weight gain was mainly affected by the growing and middle fattening period in Hanwoo steer (Tables 3 and 4). The total feed intake of treatment was higher $(p<0.01)$ than that of $\mathrm{CON}$ in the growing period, but no significant difference was found in the other periods, which may affect the whole period of total feed intake. During the feed intake of concentrate, treatment was higher than $\mathrm{CON}$ in the first or middle fattening period $(p<0.01)$. Therefore, the feed intake of concentrate on treatment showed significantly $(p<0.01)$ higher than that of CON in the whole period. However, in the growing period and final fattening period, there were no significant differences between $\mathrm{CON}$ and treatment of the feed intake of concentrate. These results are in agreement with the results of Christensen et al. (1977) and Cho et al. (2009) who reported that the total feed intake was increased and concentrate feed intake was decreased in the group fed barley silage compared with roughage feeding system in cows. No significant differences were observed in feed efficiency and feed conversion ratio between $\mathrm{T}$ and CON groups in each period of Hanwoo steer $(p>0.05)$. Thomas et al. (1988) and Baker et al. (1992) reported that diets containing a high proportion of grass silage have sustained lower growth rates and resulted in a greater fat 
deposition in the grain-fed beef when cattle were given high-concentrate diets in the forms of similar amount of energy and protein. However, the feed conversion ratio of treatment was significantly $(p<0.05)$ higher than CON in the whole period.

\section{Carcass characteristics}

The effect of IRG silage/concentrate on carcass yield and quality traits of Hanwoo steer is shown in Table 6A. The carcass fed IRG silage/concentrated diet significantly increased back-fat thickness and rib-eye area of Hanwoo steers comparing with the CON diet $(p<0.05)$. However, slaughter weight, dressing percentage, quantity grade and quality traits (marbling score, meat color, fat color, texture, matures, and quality grade) of carcass from Hanwoo steers fed either IRG silage/concentrate or rice straw/concentrate diet were similar. These results are in agreement with the results of Kim et al. (2003) who reported that feeding silage affected the back-fat thickness and rib-eye area in steers. Previous research (Steen, 1995) has reported similar findings but have also reported that the carcass weight of steer significantly reduced when concentrate intake reduced, which is in disagreement with our data.

\section{Meat characteristics}

Table 6B shows that the chemical composition and meat qualities of M. longissimusdorsi (LM) of Hanwoo steer fed IRG silage/concentrate. LM from IRG silage/ concentrate diet based production systems resulted in lighter $\left(\mathrm{L}^{*}\right)$ carcasses with higher fat and lower moisture compared to the LM from rice straw/concentrate diet $(p<0.05)$. Similar to the present study, Duckett et al. (1993) found that intramuscular fat content and palatability can be increased by switching from a forage diet to a high concentrate diet 84-196 d prior to slaughter. Furthermore, Schnell et al. (1997) and French et al. (2001) have reported that cattle finished on forage have subcutaneous fat that is more yellow in color compared to cattle finished on grain, which may be a disadvantage for consumer acceptance of forage finished beef. However, the crude protein and ash compositions of meat composition and redness $\left(\mathrm{a}^{*}\right)$ and yellowness $\left(\mathrm{b}^{*}\right)$ values of meat surface color between test diets were similar. Vestergaard et al. (2000) mentioned that postmortem glycogen is converted to lactate and $\mathrm{H}^{+}$resulting in a decrease in $\mathrm{pH}$ of the meat, and the glycogen level at slaughter is inversely related to the ultimate $\mathrm{pH}$. Monin and Sellier (1985) suggested that a high energy diet increased capacity for post-
Table 6A. Effects of feeding IRG silage/concentrate on carcass yield and quality traits of Hanwoo steer

\begin{tabular}{|c|c|c|c|c|}
\hline & $\mathrm{CON}^{1}$ & $\overline{\mathrm{T}^{2}}$ & $\overline{\text { SEM }^{3}}$ & $\overline{\operatorname{Pr}>F^{4}}$ \\
\hline \multicolumn{5}{|l|}{ Carcass yield traits } \\
\hline Back fat thickness $(\mathrm{cm})$ & 10.50 & 14.50 & 1.23 & 0.03 \\
\hline Rib-eye area $\left(\mathrm{cm}^{2}\right)$ & 83.00 & 91.10 & 2.54 & 0.04 \\
\hline Slaughter weight $(\mathrm{kg})$ & 400.60 & 429.10 & 11.75 & 0.10 \\
\hline Dressing percent (\%) & 65.93 & 63.89 & 0.82 & 0.10 \\
\hline Quantity grade ${ }^{5}$ & 4.20 & 3.90 & 0.19 & 0.28 \\
\hline \multicolumn{5}{|l|}{ Quality traits } \\
\hline Marbling score ${ }^{6}$ & 4.30 & 4.60 & 0.74 & 0.78 \\
\hline Meat color ${ }^{7}$ & 4.80 & 5.00 & 0.21 & 0.50 \\
\hline Fat color ${ }^{8}$ & 2.90 & 3.00 & 0.07 & 0.33 \\
\hline Texture $^{9}$ & 1.60 & 1.50 & 0.16 & 0.67 \\
\hline Mature $^{10}$ & 2.00 & 1.50 & 0.24 & 0.16 \\
\hline Quality grade $^{11}$ & 3.90 & 4.80 & 0.37 & 0.10 \\
\hline Total Price $(W)$ & $6,099,111$ & $6,860,567$ & 337,726 & 0.15 \\
\hline
\end{tabular}

${ }^{1} \mathrm{CON}$ : Hanwoo steer fed rice straw+concentrate. ${ }^{2} \mathrm{~T}$ : Hanwoo steer fed Italian ryegrass silage+concentrate. ${ }^{3}$ Standard error of the mean. ${ }^{4}$ Probability levels. ${ }^{5}$ grade A (5 point) $\sim$ grade D ( 2 point). ${ }^{6}$ low fat (1 point $) \sim$ high fat $(5$ point $) .{ }^{7}$ very light cherry red $(1$ point $) \sim$ very dark red $(7$ point $) .{ }^{8}$ white $(1$ point $) \sim$ yellow $(7$ point $) .{ }^{9}$ very fine ( 1 point $) \sim$ very coarse $(3$ point $) .{ }^{10}$ below 15 month old ( 1 point $) \sim$ from 15 to 26 month old ( 2 point). ${ }^{11}$ grade $1^{+}$(7 point) $\sim$ grade 3 (1 point).

Table 6B. Chemical composition and meat qualities of M. longissimus dorsi from Hanwoo steer fed IRG silage/ concentrate

\begin{tabular}{lcccc}
\hline \hline & $\mathrm{CON}^{1}$ & $\mathrm{~T}^{2}$ & $\mathrm{SEM}^{3}$ & $\mathrm{Pr}>\mathrm{F}^{4}$ \\
\hline Chemical composition & & & & \\
Moisture & 68.17 & 63.42 & 1.22 & 0.03 \\
Crude fat & 11.33 & 17.14 & 1.19 & 0.01 \\
Crude protein & 19.95 & 20.42 & 0.73 & 0.67 \\
Ash & 0.86 & 0.91 & 0.02 & 0.06 \\
\hline Meat qualities & & & & \\
Cooking loss (\%) & 24.10 & 23.59 & 1.02 & 0.14 \\
Shear force (kg) & 3.82 & 3.57 & 0.11 & 0.21 \\
Water holding capacity & 55.68 & 55.05 & 1.08 & 0.64 \\
pH & 5.64 & 5.54 & 0.01 & 0.05 \\
\hline Surface Color & & & & \\
L* & 38.64 & 41.90 & 0.12 & 0.00 \\
a* & 23.29 & 23.43 & 0.24 & 0.78 \\
b* & 10.94 & 11.97 & 0.13 & 0.52 \\
\hline
\end{tabular}

${ }^{1} \mathrm{CON}$ : Hanwoo steer fed rice straw+concentrate, ${ }^{2} \mathrm{~T}$ : Hanwoo steer fed Italian ryegrass silage+concentrate. ${ }^{3}$ Standard error of the mean. ${ }^{4}$ Probability levels.

mortem glycolysis, which would lead to an extended $\mathrm{pH}$ decline and lower ultimate $\mathrm{pH}$. However, in this study, the LM from IRG silage/concentrate diet had significantly $(p<0.05)$ higher $\mathrm{pH}$ value than the LM from rice straw/concentrate diet $(\mathrm{CON})$.

The fatty acid compositions of LM from Hanwoo steer fed IRG silage/concentrate diet is shown in Table 6C. The 
Table 6C. Fatty acid contents in the M. longissimus dorsi of Hanwoo steer fed IRG silage/concentrate

\begin{tabular}{ccccc}
\hline \hline & CON $^{1}$ & $\mathrm{~T}^{2}$ & SEM $^{3}$ & $\operatorname{Pr}>\mathrm{F}^{4}$ \\
\hline Myristic & 3.62 & 3.18 & 0.28 & 0.30 \\
Palmitic & 27.69 & 27.07 & 1.04 & 0.69 \\
Palmitoleic & 5.12 & 4.45 & 0.41 & 0.29 \\
Stearic & 11.64 & 11.74 & 0.44 & 0.87 \\
Oleic & 48.87 & 50.08 & 1.17 & 0.49 \\
Vaccenic & 0.17 & 0.59 & 0.25 & 0.28 \\
Linoleic & 1.74 & 1.82 & 0.14 & 0.72 \\
Y-linolenic & 0.08 & 0.09 & 0.01 & 0.46 \\
Linolenic & 0.20 & 0.23 & 0.03 & 0.46 \\
Eicosenoic & 0.48 & 0.58 & 0.04 & 0.10 \\
Arahidonic & 0.20 & 0.16 & 0.03 & 0.43 \\
EFA & 51.26 & 52.98 & 1.22 & 0.35 \\
SFA & 42.95 & 41.99 & 1.08 & 0.55 \\
USFA & 56.86 & 58.01 & 1.05 & 0.46 \\
MSFA & 54.64 & 55.70 & 1.02 & 0.48 \\
PUFA & 2.22 & 2.31 & 0.19 & 0.75 \\
N-3 & 0.20 & 0.23 & 0.03 & 0.46 \\
N-6 & 2.02 & 2.08 & 0.17 & 0.82 \\
\hline
\end{tabular}

${ }^{1} \mathrm{CON}$ : Hanwoo steer fed rice straw+concentrate, ${ }^{2} \mathrm{~T}$ : Hanwoo steer fed Italian ryegrass silage+concentrate. ${ }^{3}$ Standard error of the mean. ${ }^{4}$ Probability levels. EFA=Essential fatty acid. SFA=Saturated fatty acid. USFA=Unsaturated fatty acid. MUFA=monounsaturated fatty acid. PUFA=Polyunsaturated fatty acid.

fatty acid composition of meat (muscle and adipose tissue) is important for two main reasons: it determines nutritional value and it affects various aspects of meat quality, including shelf life and flavour (Wood et al., 2003). Previous research (Melton et al., 1982; Scollan et al., 2001) has reported similar findings like forage-based beef had higher concentrations of n3 PUFA than concentrate-based beef. However, our results were in disagreement with those studies. No significant differences were found in fatty acid compositions between tested groups $(p>0.05)$. The overall results showed that feeding IRG silage had significant increase crude fat and lightness $\left(\mathrm{L}^{*}\right)$ and decrease $\mathrm{pH}$ and moisture of Hanwoo beef, and the increase of rib-eye area, back fat thickness and slaughter weight of the carcass trait. In addition, feeding IRG silage to Hanwoo steer showed $12.5 \%$ higher yield than $\mathrm{CON}$ diet in an economic perspective.

\section{Acknowledgements}

We would like to thank Minister for Food, Agriculture, Forestry and Fisheries, for their support to carry out this project under the grant No. PJ006619. We also extend our gratitude to NIAS, RDA for their support. Authors thank Woosung Feed Co., Korea for feed cattle farming pro- gram during all experiment period.

\section{References}

1. AOAC (1995) Official Methods of Analysis. 16th ed, Association of Official Analytical Chemists, Washington, DC.

2. Baker, R. D., Young, N. E., and Laws, J. A. (1992) The effect of diet in winter on the body composition of young steers and subsequent performance during the grazing season. J. Ani. Product. 54, 211-219.

3. Bocquier, F. and Caja, G. (2001) Production et composition du lait de brebis: Effets de l'alimentation. INRA Production Animal 14, 129-140.

4. Chilliard, Y., Ferlay, A., Rouel, J., and Lamberet, G. (2003) A review of nutritional and physiological factors affecting goat milk lipid synthesis and lipolysis. J. Dairy Sci. 86, 1751-1770.

5. Cho, W. M., Chang, S. S., Cho, Y. M., Kim, H, C., Kwon, E. G., Yang, S. H., and Paek, B. H. (2009) Effects of forage source and shipping time on growth performance and carcass characteristics of Hanwoo steers. J. Korean Soc. Grassl. Forage Sci. 29, 375-382.

6. Christensen, D. A., Owen, B. D., Steacy, G., Crowle, W. L., and Mtimuni, J. P. (1977) Nutritive value of whole crop silage made from seven cereal cultivars. Can. J. Anim. Sci. 57, 537-542.

7. Duckett, S. K., Wagner, D. G., Yates, L. D., Dolezal, H. G., and May, S. G. (1993) Effects of time on feed on beef nutrient composition. J. Anim. Sci. 71, 2079-2088.

8. Folch, J., Lee, M., and Stanley, G. H. S. (1957) A simple method for the isolation and purification of total lipids from animal tissue. J. Biol. Chem. 226, 497-509.

9. French, P., O’Riordan, E. G., Monahan, F. J., Caffrey, P. J., Mooney, M. T., Troy, D. J., and Moloney, A. P. (2001) The eating quality of meat of steers fed grass and/or concentrates. Meat Sci. 57, 379-386.

10. Jensen, R. G. (2002) The composition of bovine milk lipids: January 1995 to December 2000. J. Dairy Sci. 85, 295-350.

11. Kang, S. N., Song, Y. M., Kim, C. W., Kim, T. W., Chu, G. M., Yang, B. S., Jin, S. K., and Kim, I. S. (2010) Effect of feeding high carbohydrate-low fat fermented fed on the meat quality characteristics in finishing pigs. Korean J. Food Sci. An. 30, 826-832.

12. Keating, T., O'kiely, P., and Keane, G. P. (1990) Beef production from Loliummultiflorum, Loliumperenne and permanent grassland swards. Ani. Prod. 50, 584.

13. Kim, W. H., Se, S., Yun, S. H., Kim K. Y., Cho, Y. M., Park, T. I., Ko, J. M., and Park, K. J. (2003) Selection of promising barley cultivar for silage 2 . Nutrient value and total digestibility nutrient yield. J. Korean Soc. Grassl. Forage Sci. 23, 283288.

14. Kunelius, H. T. and Narasimhalu, P. (1983) Yields and quality of Italian and Westerwolds ryegrasses, red clover, alfalfa, birdsfoot trefoil, and Persian clover grown in monoculturesand-ryegrass-legume mixtures. Can. J. Plant Sci. 63, 437-442.

15. Lepage, G. and Roy, C. C. (1986) Direct trans esterification of all classes of lipid in a one-step reaction. J. Lipid Res. 27, 
114-121.

16. McDonald, P. and Edwards, R. A. (1976) The influence of conservation methods on digestion and utilization of forages by ruminants. Proc. Nutr. Soc. 35, 201-211.

17. McGee, M. (2005) Recent developments in feeding beef cattle on grass silage-based diets. In: Silage Production and Utilisation. R.S. Park, \& M. D. Stronge (Eds), Proceedings of the $X V t h$ International Silage Conference. Wageningen Academic Publishers, Wageningen, The Netherlands, pp. 51-64.

18. McIsacc, J. A. and Lovering, J. (1982) An economic comparison of timothy, corn and Westerwolds ryegrass as conserved forages for dairy cows. Can. J. Plant Sci. 62, 649-655.

19. Melton, S. L., Amiri, M., Davis, G. W., and Backus, W. R. (1982) Flavor and chemical characteristics of ground beef from grass-, forage-grain- and grain-finished steers. J. Anim. Sci. 35, 77787.

20. Ministry for Food, Agriculture, Forestry \& Fisheries (MFAFF) (2007) Korean feeding standard for Hanwoo (Korean native cattle). Seoul, Korea.

21. Monin, G. and Sellier, P. (1985) Pork of low technological quality with normal rate of muscle $\mathrm{pH}$ fall in the immediate post-mortem period: The case of the Hampshire breed. Meat Sci. 13, 49-63.

22. Narasimhalu, P., Kunelius, H. T., McRae, K. B., and Winter, K. A. (1985) Composition, intake and digestibility of timothy and Italian and Westerwolds ryegrass silages. Can. J. Plant Sci. 65, 99-105.

23. National Research Council (NRC) (2001) Nutrient Requirements of Dairy Cattle, 7th Revised Edition. National Academy of Sciences, National Academy Press, Washington DC, USA.

24. O'Riordan, E. G., McGilloway, D., and French, P. (2000) Beef from grass-based system. Ir. Grassl. Ani. Prod. Assoc. J. 34, 105-111.

25. Petit, H. V., Veira, D. M., and Yu, Y. (1994) Growth and carcass characteristics of beef steers fed silage and different levels of energy with or without protein supplementation. J. Anim. Sci. 72, 3221-3229.

26. Razminowicz, R. H., Kreuzer, M., and Scheeder, M. R. L. (2006) Quality of retail beef from two grass-based production systems in comparison with conventional beef. Meat Sci. 73,
351-361.

27. SAS (2002) SAS Procedures Guide release 9.0 SAS institute Inc., Cary, NC. U.S.

28. Schnell, T. D., Belk, K. E., Tatum, J. D., Miller, R. K., and Smith, G. C. (1997) Performance, carcass, and palatability traits for cull cows fed high-energy concentrate diets for 0 , 14, 28, 42, or 56 days. J. Anim. Sci. 75, 1195-1202.

29. Scollan, N. D., Choi, N. J., Kurt, E., Fisher, A. V., Enser, M., and Wood, J. D. (2001) Manipulating the fatty acid composition of muscle and adipose tissue in beef cattle. British $J$. Nutr. 85, 1151124.

30. Shinekhuu, J., Jin, G. L., Ji, B. J., Li, X. Z., Oh, Y. K., Hong, S. K., and Song, M. K. (2010) Protein fractionation of whole crop silages, and effect of borate-phosphate buffer extraction on in vitro fermentation characteristics, gas production and degradation. Kor. J. Anim. Sci. Technol. 51, 369-378.

31. Snedecor, G. W. and Cochran, W. G. (1968) Statistical Methods. 6th ed, The Iowa State University Press, Ames, Iowa.

32. Steen, R. W. J. (1984). A comparison of two-cut and threecut systems of silage making for beef cattle using two cultivars of perennial ryegrass. Anim. Prod. 38, 171-179.

33. Steen, R. W. J. (1995) The effect of plane of nutrition and slaughter weight on growth and feed efficiency in bulls, steers and heifers of three breed crosses. Livest. Prod. Sci. 42, 1-11.

34. Thomas, D., Gibbs, B. G., Beever, D. E., and Thurnham, B. R. (1988) The effect of date of cut and barley substitution on gain and on the efficiency of utilization of grass silage by growing cattle. Br. J. Nutr. 60, 297-306.

35. Veira, D. M., Proulz, J. G., Butlen, G., and Fortin, A. (1988) Utilization of grass silage by cattle: Further observations on the effect of fishmeal. Can. J. Anim. Sci. 68, 1225-1235.

36. Vestergaard, M., Oksbjerg, N., and Henckel, P. (2000) Influence of feeding intensity, grazing and finishing feeding on muscle fibre characteristics and meat colour of semitendinosus, longissimus dorsi and suprasinatus muscles of young bulls. Meat Sci. 54, 177-185.

37. Wood, J. D., Richardson, R. I., Nute, G. R., Fisher, A. V., Campo, M. M., Kasapidou, E., Sheard, P. R., and Enser, M. (2003) Effects of fatty acids on meat quality: A review. Meat Sci. 66, 21-32. 